Lazebnyk O. O., Postgraduate Student European University Kyiv, Ukraine

DOI: https://doi.org/10.30525/978-9934-26-028-5-15

\title{
RELEVANCE OF E-COMMERCE DURING QUARANTINE RESTRICTIONS AT THE EXAMPLE OF BOTTLED WATER TRADE
}

Nowadays the trend for buying various goods on the Internet has been showing a rapid growth, and in terms of quarantine restrictions which took place in 2020 due to global COVID-19 pandemic this issue has become quite acute. Throughout the last decade the leading demand for online purchase in Ukraine had consumer electronics, clothes and footwear, but as for food and drinks, most Ukrainians do not tend to buy the products of such category online [1].

However, the quarantine has changed this trend dramatically, because the number of people infected by COVID-19 has been growing almost every day. Due to this reason in spring 2020, when the symptoms and consequences of this illness were not researched enough, Ukrainians were highly recommended to stay at home, 
especially as supermarkets and other food stores are one of the main causes of virus spread because of large crowds. According to Nielsen research held in March 2020, 41\% of surveyed Ukrainians living in cities with population over 50000 residents have the experience of purchasing food online, and $9 \%$ of the whole survey pool began doing it on a regular basis after the announcement about the rising trend of COVID-19 pandemic [2].

Let us analyze the pros and cons of online purchase during quarantine restrictions at the example of bottled water. For over 3 years IDS Borjomi Ukraine, the leader of Ukrainian bottled mineral water market [3, p. 112], has been selling the products offered under its trademarks (Morshynska, Borjomi, Myrgorodska, Truskavetska, Aqua Life, Morshynka, Aqua Nanny and Alaska) via My Water Shop (mywatershop.ua), the company's own official Internet store [4]. To understand whether it is relevant to sell bottled water via online platform, especially in terms of quarantine restrictions, it would be a good idea to conduct SWOT Analysis of My Water Shop (see figure 1).

\begin{tabular}{|c|c|}
\hline Strengths & Weaknesses \\
\hline $\begin{array}{l}\text { - company's own distribution network } \\
\text { - possibility of delivery for free } \\
\text { - unique mineral water structures } \\
\text { - massive promotional campaign } \\
\text { - trademarks that are mostly favoured } \\
\text { by Ukrainians } \\
\text { - offer of additional products and } \\
\text { accessories }\end{array}$ & $\begin{array}{l}\text { - only several bottles of water in one } \\
\text { package (except for bottles } 18.9 \mathrm{~L} \text { ) can } \\
\text { be purchased } \\
\text { - no opportunity to view and touch the } \\
\text { product before having at delivered } \\
\text { - waiting for delivery is inevitable }\end{array}$ \\
\hline Opportunities & Threats \\
\hline $\begin{array}{l}\text { - recommendation to stay at home } \\
\text { - growing demand for online purchase } \\
\text { - trend for healthy lifestyle } \\
\text { - low tap water quality }\end{array}$ & $\begin{array}{l}\text { - potential newcomers specialized in } \\
\text { bottled water e-commerce } \\
\text { - poorly developed bottled water } \\
\text { drinking culture } \\
\text { - pressure from other soft drinks } \\
\text { manufacturers } \\
\text { - lack of online purchase experience } \\
\text { among population } \\
\text { - economic or ecologic crisis }\end{array}$ \\
\hline
\end{tabular}

Figure 1. SWOT Analysis of My Water Shop online store Source: [1-5] 
My Water Shop has many strong characteristics. Firstly, this is the online store run directly by IDS Borjomi Ukraine, that is why no other intermediates and distributors are involved in the delivery process. Secondly, if the total cost for booked products exceeds $200 \mathrm{UAH}$, then the delivery is carried out for free [5]. Furthermore, the water that is bottled at IDS Borjomi Ukraine production capacities is extracted from totally clean mineral springs that have unique structures. That makes the products indispensable. Moreover, due to massive promotional activities two IDS brands, Morshynska and Borjomi, are the most favourite ones among the Ukrainians [3, p. 112], and since the beginning of the quarantine My Water Shop has been heavily advertised in mass media (including TV, banners and YouTube). During the spring 2020 lockdown the key message of that campaign was to stay at home and book the water online. In addition to this, apart from bottled water My Water Shop offers some other products, such as tea, coffee, milk, and accessories like water pumps, coolers and other related equipment [4].

Currently there are no obvious weak points of My Water Shop, but unlike traditional offline shop or kiosk, where it is possible to buy one bottle of water, this online store allows to book only a pack of 2, 4, 6, 8 or 12 bottles (dependent on water trademark and bottle size) [4]. What is more, like any online store My Water Shop does not allow to see the product exactly and to touch it like it can be done in offline store, and the reality of online purchase is that waiting until the booked product is delivered is inevitable.

The main opportunity for My Water Shop is that its customers do not have to leave their homes so as to buy bottled water, which is relevant in terms of quarantine, and the recommendation to stay at home has driven online sales [2]. Moreover, the trend for a healthy lifestyle, which has been taking place in Ukraine for several years, is a powerful way to boost mineral water sales [3, p. 110]. In addition to this, unlike many European countries, where tap water is clean and safe, the quality of Ukraine's tap water is low, and this leads to a growing demand for bottled water [3, p. 110]. 
Apart from opportunities, there are some threats that are likely to prevent My Water Shop from development. Firstly, there is always a possibility of potential newcomers specialized in selling bottled water via the Internet. Secondly, despite the large number of mineral springs Ukraine's bottled water drinking culture is poor, which is mainly the result of low solvency of average Ukrainian. Furthermore, there is a pressure from manufacturers of drinks like lemonade or cola, and youngsters under 26 years old are heavily impacted by their marketing activities [3, p. 107]. As a result, there are fewer mineral water customers. What is more, most Ukrainians are not used to buying food online for several reasons:

1. Tradition to choose products independently and not to rely on delivery services.

2. Imperfection of delivery services and processes.

3. Lack of confidence in quality of delivered commodities [1].

Finally, nobody is protected from the danger of economic or ecologic crisis, which can result, for example, in low salaries, unemployment, natural disasters and other unpredictable consequences that can have an impact on the purchase and consumption of bottled water. COVID-19 pandemic is one of the examples that has caused strong unemployment around the world since it affected global economics heavily.

Taking everything into consideration, though Ukrainian online purchasing culture is still pretty low, especially when it comes to food and drinks, quarantine restrictions due to COVID-19 pandemic have caused the rising demand for booking such stuff via the Internet, and bottled water is no exception. The trend for a healthy lifestyle among Ukrainians leads to the popularity of bottled mineral water consumption, and the wish to be protected from infections encourages to follow quarantine rules. These are the factors that promote the development of My Water Shop as well as online food and drink sales in general. 


\section{References:}

1. Melnyk O. (2017) Yizha internetom - realiyi onlain-prodazhu v ukrayinskykh FMCG-merezhakh [Food by Internet - realities of online sales in Ukrainian FMCG networks] (online). Na chasi (viewed 15 January 2021). URL: https://nachasi.com/ 2017/07/17/online-food.

2. Nagorskii V. (2020) Azhiotazh v merezhi: iak ukrayinski supermarkety spravliayutsia zi zrostanniam onlain-pokupok i popytom na dostavku [Hype in the net: how Ukrainian supermarkets cope with the growth of online purchases and demand for deliveries] (online). Retail Association of Ukraine (RAU) (viewed 15 January 2021). URL: https://rau.ua/novyni/novini-kompanij/supermarkety-na-dostavku.

3. Lazebnyk O., Vasiutkina N. (2020) Research of Bottled Water Consumers' Behaviour in Europe and Ukraine Considering Current Economic and Environmental Conditions. Journal of Hygienic Engineering \& Design (JHED). Skopje, North Macedonia. Vol. 32, pp. 106-113.

4. My Water Shop (online). IDS Borjomi Ukraine (viewed 17 January 2021). URL: https://mywatershop.ua.

5. Etapy dostavky [Delivery stages] (online), IDS Borjomi Ukraine (viewed 17 January 2021). URL: https://mywatershop.ua/delivery. 